\title{
Packaging, storage and value addition of aonla, an underutilized fruit, in India
}

\author{
Vijaykumar T. KORE ${ }^{1 *}$, H. Lembisana DEVI ${ }^{2}$, J. KABIR ${ }^{1}$
}

\begin{abstract}
${ }^{1}$ Dep. Postharvest Technol. Hortic. Crops, Bidhan Chandra Krishi Viswavidyalaya, Mohanpur, Dist. Nadia, West Bengal - 741252, India, korevijay56@gmail.com, j_kabir@rediffmail.com

2 Dep. Fruits Orchard Manag., Bidhan Chandra Krishi Viswavidyalaya, Mohanpur, Dist. Nadia,

West Bengal - 741252, India
\end{abstract}

${ }^{*}$ Correspondence and reprints

Fruits, 2013, vol. 68, p. 255-266 (C) 2013 Cirad/EDP Sciences All rights reserved DOI: $10.1051 /$ fruits/2013064 www.fruits-journal.org

RESUMEN ESPAÑOL, p. 266
Packaging, storage and value addition of aonla, an underutilized fruit, in India.

Abstract - The product. Aonla (Emblica officinalis Geartn), the king of arid fruits, popularly known as "Indian gooseberry", is a small-sized minor subtropical fruit grown widely in North India. India ranks first in the world in aonla area and production volume. It is considered to be a "wonder fruit for health" because of its unique properties. Uses. Aonla fruit is very useful in treating many diseases such as diabetes, cough, asthma, bronchitis, headache, dyspepsia, colic, flatulence, skin diseases, leprosy, jaundice, scurvy, diarrhea and cancer. Packaging. Different packaging materials such as nylon net, perforated polyethylene bags, ventilated corrugated fiber boxes, gunny bags, wooden crates, etc., can be used for prolonging the storage life of fruit. Storage. Refrigerated storage helps in enhancing the storage life of fruit. Value addition. There are numerous products such as aonla squash, candy, jam, chutney, etc., which are prepared from aonla fruit. Inclusion of these products in the diet definitely helps in improving the nutritional value of Indian meals. Discussion. The low cost of the products as well as good sensory, nutritional and shelf life qualities mean that processed aonla products are appropriate for commercialization. In order to obtain a good income from aonla, it must be sold immediately in the market; if not, to make profit, proper storage facilities should be available.

Emblica officinalis / fruits / traditional uses / packaging equipment / storage / value added

Emballage, stockage et valeur ajoutée de l'aonla, un fruit sous-utilisé, en Inde.

Résumé - Le produit. L'aonla (Emblica officinalis Geartn.), roi des fruits des zones arides, populairement connu sous le nom de "groseille indienne", est un petit fruit subtropical mineur largement cultivé en Inde du Nord. L'Inde occupe la première place mondiale en superficie et en volume de production de ce fruit. Il est considéré comme un "fruit étonnant pour la santé " en raison de ses propriétés exceptionnelles. Utilisations. Le fruit de l'aonla est très utilisé pour soigner de nombreuses maladies comme le diabète, la toux, l'asthme, la bronchite, les maux de tête, la dyspepsie, les coliques, les flatulences, les maladies de peau, la lèpre, la jaunisse, le scorbut, la diarrhée et le cancer. Emballage. Différents matériaux d'emballage tels que filets en nylon, sacs de polyéthylène perforés, boîtes en carton ondulé ventilé, sacs de jute, caisses en bois, etc., peuvent être utilisés pour prolonger la durée de conservation des fruits. Stockage. Le stockage réfrigéré permet d'améliorer la durée de conservation des fruits. Valeur ajoutée. Un très grand nombre de produits comme le jus pressé, les bonbons, la confiture, le chutney, etc., sont préparés à partir de fruits de l'aonla. L'introduction de ces produits dans l'alimentation contribue à l'amélioration de la valeur nutritionnelle des repas indiens. Discussion. Le faible coût des produits ainsi que ses bonnes qualités sensorielles, nutritionnelles et de durée de vie font que les produits transformés à partir de fruits de l'aonla sont appropriés à la commercialisation. Afin d'avoir un bon revenu de l'aonla, le fruit doit être vendu rapidement sur le marché, sinon pour obtenir des bénéfices, il est nécessaire de disposer d'installations de stockage adéquates.

Emblica officinalis / fruits / utilisation traditionnelle / matériel d'emballage / stockage / valeur ajoutée

Article published by EDP Sciences 


\section{Introduction}

Aonla (Emblica officinalis Geartn) is one of the oldest minor fruits of India and considered to be a "wonder fruit for health" because of its unique properties. It belongs to the family Euphorbeaceae and is native to India, Sri Lanka, Malaysia and China [1] It is one of the most important fruits of the tropics and subtropics of the Indian subcontinent [2]. The indigenous fruit has extensive adaptability to grow in diverse climatic and soil conditions. It is known by different names such as 'Amla', 'Amalakki', 'Nelli', 'Indian gooseberry', etc. Being a very rich source of vitamin C [(500 to1500) $\mathrm{mg}$ ascorbic acid $100 \mathrm{~g}^{-1}$ of pulp] [3-5] and of other nutrients such as polyphenols, pectin, iron, calcium and phosphorus [6-8], the fruit is a potent antioxidant [9], hypolipidemic and antibacterial [10]; it has antiviral and antacid properties. However, owing to its highly acidic and astringent taste, low total soluble solids (TSS), and poor flavor and color, it is not popular as a table fruit [1].

The fruit is highly perishable in nature; in India, it is available for a short period from October to January $[11,12]$. Its storage life in atmospheric conditions after harvesting is only 5-6 days [13]. Appropriate storage and processing methods can curtail the postharvest losses to 30\% [14] and make the fruit available for longer [15]. The few postharvest technologies that exist are complex and are unaffordable to small farmers at the farm level $[12,16]$. Due to its astringent nature, consumers are hesitant to eat it in raw form. Attempts are being made to produce valueadded products which are not only nutritious but also accepted by consumers [14].

Thus, the objective of our review was to explore the packaging, storage and value addition technologies available to reduce the postharvest losses of aonla fruit.

\section{Uses}

Aonla fruit is very useful in treating many diseases such as diabetes [17-20], cough [21], asthma [22], bronchitis, headache [23], ophthalmic disorders, dyspepsia, colic, flatulence, skin diseases [24], leprosy, jaundice, scurvy, diarrhea [25], grayness of hair [26] and cancer (e.g., liver cancer and skin cancer) [27-32]. The fruit is used as an antiscorbutic, diuretic and laxative [7, 3335 ], and for treating the common cold, gastric troubles, acidity, scurvy [36, 37], dysentery, bronchitis, diabetes [17, 18], jaundice and dyspepsia [36, 38]. Dried fruits are useful in chronic dysentery, diarrhea, diabetes, dyspepsia, cough, anemia and jaundice $[36,39,40]$. Aonla is one of the three constituents of the famous ayurvedic preparation, 'triphala', which is prescribed in many digestive disorders [41].

The edible fruit tissues of aonla contain about 3 times more protein and 160 times more vitamin $\mathrm{C}$ as compared with apples [42]. Normally, a single aonla fruit contains 20 times more vitamin $\mathrm{C}$ than two oranges.

\section{Packaging}

There is a linear increase in quality parameters (such as specific gravity, TSS, acidity, the [TSS:acid] ratio, fiber content, etc.) from 35 days old to fully matured fruit (120 days) of aonla, and hence it is ideal to harvest fruits at 120 days after set [43]. The appropriate packaging has great significance in reducing the postharvest losses during transport, storage and marketing [7]. Selection of the correct packaging material and packing method are equally important. Packaging should be such that it provides protection, is easy to handle, attractive and economical. At present, proper packaging is inadequate in the case of aonla. Gunny bags and baskets are common packaging materials for this fruit, in spite of the fact that they have poor dimensional stability and stacking strength. Baskets made of pigeon pea twigs (40-45 kg capacity), lined with newspaper and aonla leaves as cushioning material, are used for packaging [44]. The capacity of gunny bags is $50 \mathrm{~kg}$ to $100 \mathrm{~kg}$. In these bags, however, the fruits are injured by impact, vibration and compression during transportation. Corrugated fiber board (CFB) boxes are better as they provide appropriate ventilation inside the 
box, printable information at low cost and are recyclable. Newspaper lining should be provided inside the CFB cartons. The appropriate size of boxes for $20 \mathrm{~kg}$ capacity should be used. Minimum spoilage (16.0\%) was noted in corrugated fiber board boxes with newspaper liner, followed by CFB boxes with polythene liner (17.0\%); spoilage was highest in gunny bags without any liner (30.19\%) after 13 days of storage [45].

Singh et al. evaluated different $40-\mathrm{kg}$ package containers during distant rail transportation, and found that a wooden crate with polythene liner is the most suitable material [7]. Weight loss and bruising were minimal in this container as compared with the gunny bag.

The comparative performance of different packaging materials was studied in the cultivars 'Chakiya' and 'Francis' packed in gunny bags, fiber carton, pigeon pea branch baskets and wooden boxes (40-kg capacity), all lined with newspaper or polythene. Studies showed that wooden boxes with polyethylene lining resulted in lower weight loss and bruising than other packaging materials [44]. Packaging of fruits in perforated polyethylene bags was effective in reducing physiological loss in weight, retention in moisture and acceptable physico-chemical quality. The shelf life of aonla fruits was extended up to 15 days at room temperature when fruits were treated with 6\% Waxol (an edible wax coating $)+\left[4 \times 10^{5} \mu \mathrm{L}\right.$ Cycocel Chlormequat Chloride (CCC) $\left.\mathrm{L}^{-1}\right]$ and packed in perforated polyethylene bags. This treatment combination recorded the maximum score for marketability among the tested treatments [46].

\section{Storage}

The fruit availability period of aonla is very short; hardly 2 to 3 months. Therefore, storage of fruits at an appropriate temperature is essential to extend the availability period and to stabilize the price in the market. Being an underutilized fruit crop, very few studies have been done on low temperature, modified atmosphere and controlled atmosphere storage of this valuable fruit.
Storage facilities such as cold storage and controlled/modified atmosphere packing are very expensive and not within the direct reach of poor farmers [12]. Excessive dehydration, decline in nutritional status and decay are the main factors limiting fruit postharvest life. Fruits of five aonla cultivars, i.e., 'Banarasi', 'Krishna', 'Francis', 'Chakaiya' and 'Kanchan', were evaluated for shelf life at ambient temperature. Studies on shelf life of aonla fruits indicated that loss in fruit weight, ascorbic acid and decay increase with length of storage period. Considering $10 \%$ loss in weight indicated that 'Chakaiya' could be stored for 9 days, while the other cultivars could be stored only for up to 6 days [6, 7]. Fruit spoilage started after 6 days of storage in 'Banarasi' and 'Krishna'.

Singh and Kumar studied the effect of different storage conditions such as temperature, modified atmosphere, zero energy cool chamber (evaporative cool chamber developed at the Indian Agricultural Research Institute) and zero energy + modified storage conditions [47]; they found that the decay loss was minimum (26.56\%) in modified storage conditions on the 24th day of storage, whereas it was maximum $(48.70 \%)$ in the zero energy chamber. The fruits may be kept in cold storage for $7-8$ days at $0{ }^{\circ} \mathrm{C}$ to $2{ }^{\circ} \mathrm{C}$ and $85-90 \%$ relative humidity. Zero energy cool chambers are designed to provide a lower temperature and higher humidity than ambient conditions but without using any power. The five cultivars, i.e., 'Banarasi', 'Krishna', 'Francis', 'Chakaiya' and 'Kanchan', were evaluated for their shelf life in the zero energy cool chamber and the results indicated that the cultivars 'Francis', 'Chakaiya' and 'Kanchan' could be stored for up to 18 days, and 'Banarasi' and 'Krishna' for up to 12 days in the zero energy cool chamber [6, 7].

During storage at $(18 \pm 2){ }^{\circ} \mathrm{C}$ and $(65 \pm 5) \%$ $\mathrm{RH}$, Singh et al. found fruit weight loss, TSS, acidity and tannins increased, while ascorbic acid content decreased in the cultivars, viz., 'NA-7', 'NA-10', 'Krishna' and 'Chakaiya' [48]. 'NA-10' and 'Krishna' exhibited minimum dehydration, and higher TSS, ascorbic acid and tannins than 'Chakaiya' and 'NA-7'. However, browning up to 
Figure 1.

Flow chart for preservation of aonla.

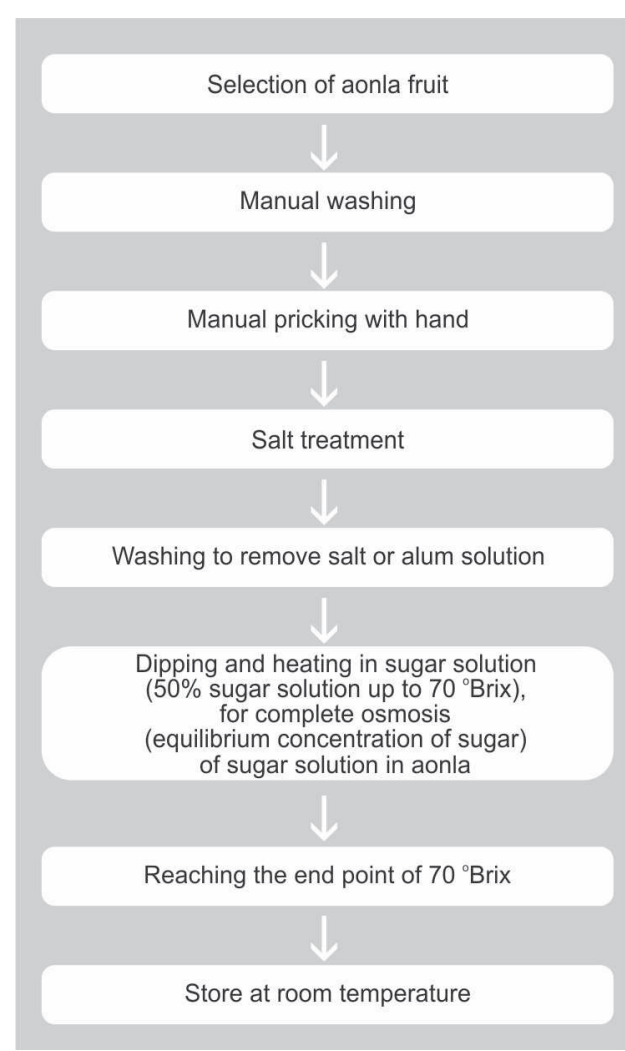

10 days of storage in the cultivar 'NA-7' was lower than in 'Krishna'. Therefore, 'NA-10' and 'Krishna' had better shelf life (10 days) and retained higher vitamin $\mathrm{C}$ content, and kept a glossy and green appearance, compared with 'NA-7', which could be stored for 6-8 days.

The aonla cultivars 'Desi' and 'Banarasi' could be stored for up to twelve days at low temperature $\left(2^{\circ} \mathrm{C}\right.$ to $\left.5^{\circ} \mathrm{C}\right)$. Cold storage at $10^{\circ} \mathrm{C}$ has been reported as the best storage in terms of the highest marketability and the lowest percentage of damaged fruits, better retention of vitamin $\mathrm{C}$ and the lowest physiological loss in weight [47].

Common salt or sodium chloride has a mild antiseptic property [49]. It is cheap and easily usable. The shelf life of aonla fruits may be extended in brine solution. Though $10-12 \%$ brine solution is good enough to prevent microbial spoilage, $15 \%$ salt solution was found to be the best in terms of physical appearance and minimum nutritive loss [47]. The fruits may be stored for up to 75 days in $15 \%$ brine solution.

\section{Value addition}

The postharvest losses in aonla vary from $30 \%$ to $40 \%$ due to its perishable nature, which reduces the market value. Value addition through processing would be the only effective tool for economic utilization of increased production of aonla in the future. Processing not only reduces the postharvest losses but also provides higher returns to the growers. A number of products such as murabba, pickle, candy, juice, squash, jam, jelly, powder, etc., are prepared from aonla fruits [14, 37, 50-52].

\subsection{Aonla preservation (murabba)}

Aonla fruits are normally used to make preserve. A preserve is made from fully matured aonla fruits by cooking them whole or in the form of large pieces in heavy sugar syrup, until it becomes tender and transparent. Though preserve ('murabba') is the most popular, delicious and highly valued product from aonla, its preparation (figure 1) is a cumbersome process involving exhaustive pricking of fruits, resulting in the loss of most of the nutrients [53]. It is claimed to impart energy to the heart and liver [54-56]. It is also reported to stop diarrhea and be useful as a remedy for giddiness [14].

\subsection{Dry products}

Dehydration is the oldest and most viable low-cost preservation technology for a small farmer to prolong the shelf life of fruits and vegetables [57, 58]. Drying is an effective method to increase the shelf life of aonla fruits. Dried fruits are useful in chronic dysentery, diarrhea, diabetes, dyspepsia, cough, anemia and jaundice [36, 39, 40]. There are numerous products that can be prepared from dry aonla fruits such as dried whole fruit, flakes [59], slices [60], supari [61], shreds [62] and powder [63]. Blanching with hot water or with potassium metabisulfite before drying prevents enzymatic browning and improves the color and texture of the shreds. Solar drying is cheaper, whereas hot air ovendrying is a more convenient method of 
removing moisture from the product (figure 2).

The dry, powdered fruit contains 6.3\% phyllemblic acid (first the sour-bitter and then the sweet astringent taste), $6 \%$ fatty matter, $5 \%$ gallic acid, ellagic acid, emblicol $\left(\mathrm{C}_{20} \mathrm{H}_{30} \mathrm{O}_{10}\right.$, a crystalline phenolic product insoluble in ether and benzene, fairly soluble in water and the alcohols) [64] and other constituents. Ethyl gallate isolated from dried fruit acts as a mild central nervous system depressant and has spasmolytic activity [43].

\subsection{Blended ready-to-serve beverages}

Ram et al. used aonla and bael fruits for blended RTS (ready-to-serve) beverages [65]. The blended RTS beverage prepared with 25\% aonla and 75\% bael (Aegle marmelos) pulp with $15^{\circ}$ Brix TSS and $0.25 \%$ titratable acidity was similar to the beverage prepared with only bael pulp; it was better than pure aonla beverages. The authors found that increased concentration of aonla pulp decreased the acceptability of the beverages.

Jain and Khurdiya conducted an experiment on aonla juice blended with apple, lime, pomegranate, Perlette grape and Pusa Navrang grape [1]. When gooseberry juice was blended with other fruit juices for the preparation of ready-to-serve (RTS) beverages, it boosted their nutritional quality in terms of vitamin $\mathrm{C}$ content. The authors found that the blending of aonla juice and grape juice [20:80] gave the best result on the basis of overall sensory quality and vitamin $\mathrm{C}$ content.

Chandan et al. prepared an aonla RTS beverage with drained aonla syrup [66]. They obtained the drained syrup from blanched slices of aonla steeped in salt for $2 \mathrm{~h}$, followed by steeping in $70^{\circ}$ Brix syrup for $24 \mathrm{~h}$, and adjusted it to $20^{\circ}$ Brix containing $2 \%$ lime juice $+1 \%$ ginger juice, which was found to be acceptable, with good organoleptic scores (figure 3).
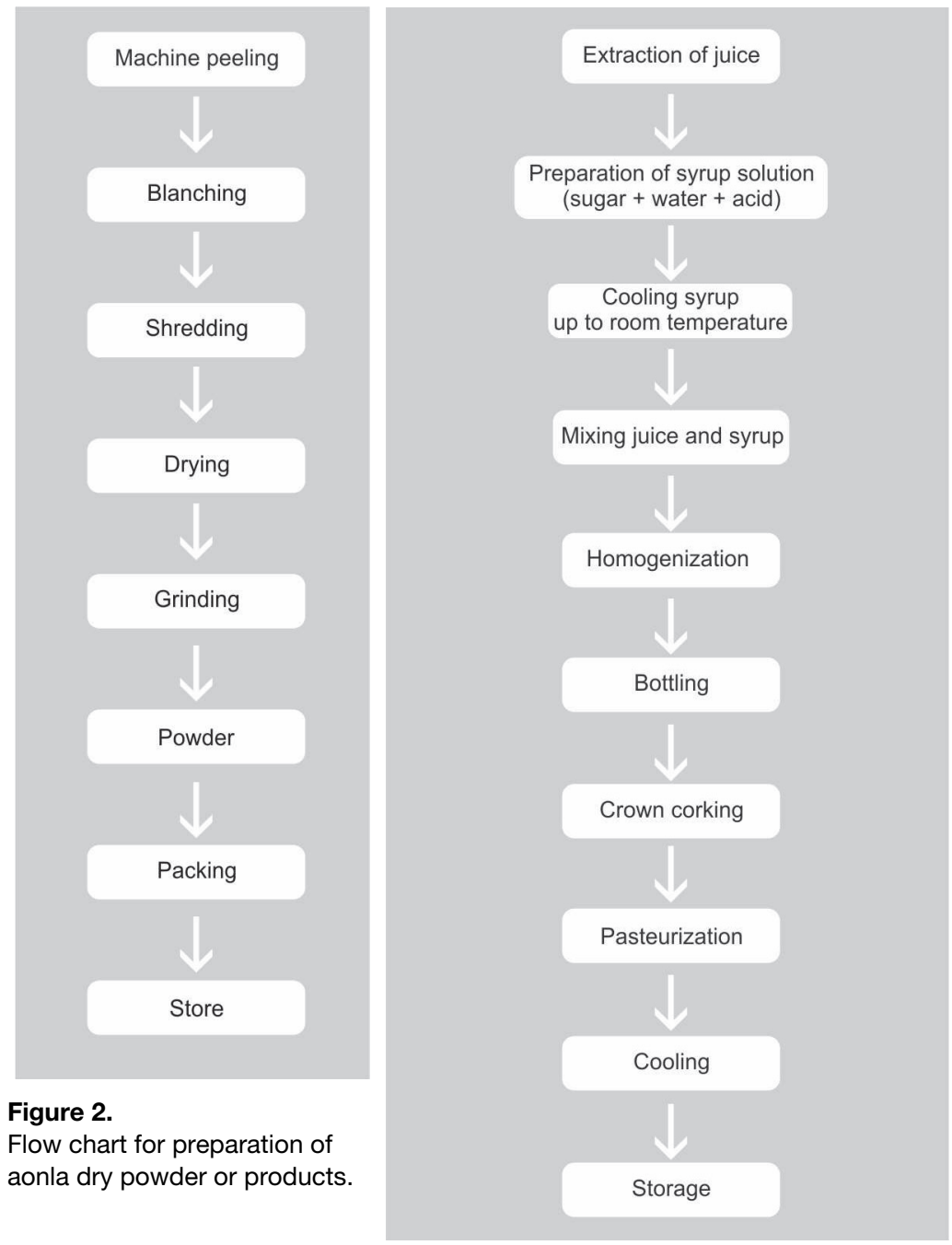

Figure 3.

Flow sheet for preparation of ready-to-serve (RTS) aonla product.

\subsection{Aonla candy}

Fruit candies are becoming more and more popular because of high acceptability, high nutritional value and longer storage life. Singh and Pathak reported that aonla fruit can be utilized for making excellent-quality candy or intermediate moisture food (IMF) [34]. Pathak described the technology for preparation of aonla candy [67]. The recipe contained $1 \mathrm{~kg}$ aonla fruit, $1 \mathrm{~kg}$ sugar and $1.5 \mathrm{~kg}$ water (figure 4). 
Figure 4.

Flow chart for preparation of aonla candy.

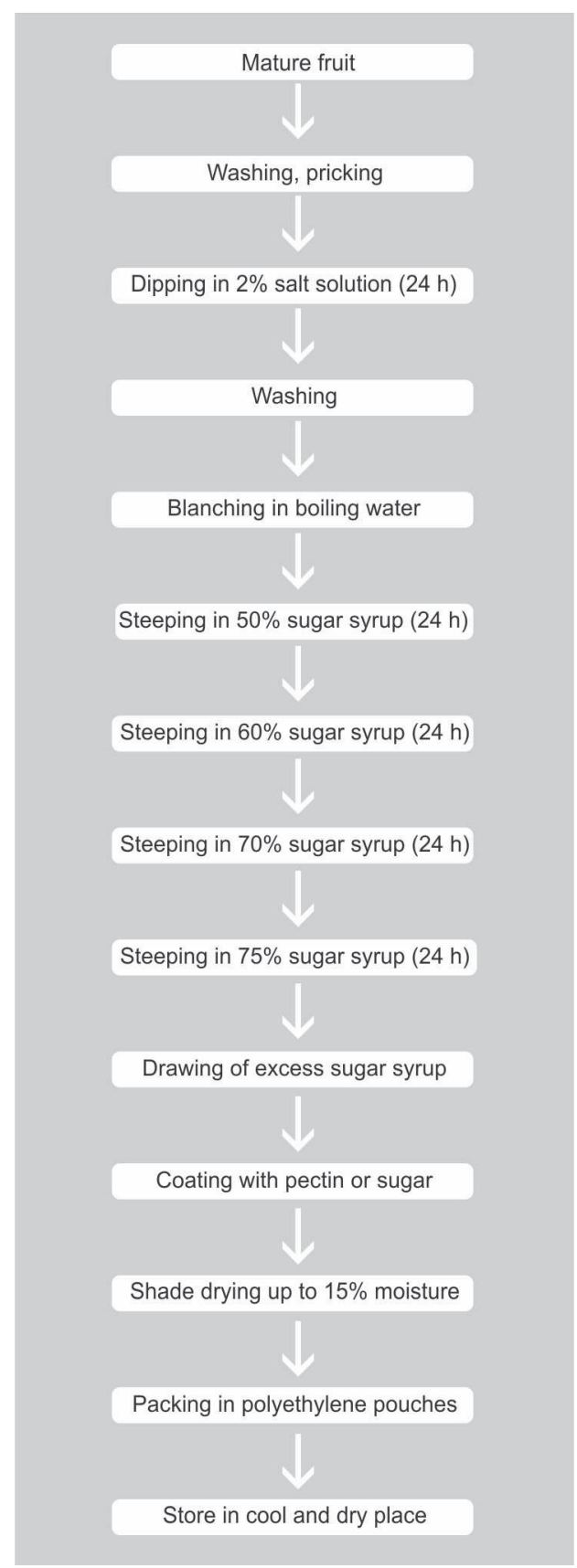

Tandon et al. studied the effect of blanching and lye peeling on candy preparation [37]. They found that the candy prepared from lye-peeled fruits of aonla showed more decreased content of ascorbic acid compared with blanched fruits. However, the effect of the blanching on some of nutritional parameters was less severe than that of lye peeling.
Singh et al. conducted a study to find out the techno-economic feasibility of processing of aonla pulp-based (jam, squash, sauce) and non-pulp-based (candy) products [68]. They found that the processing cost of $1 \mathrm{~L}$ of squash and $1 \mathrm{~kg}$ of candy was much lower than that of $1 \mathrm{~L}$ of sauce and $1 \mathrm{~kg}$ of jam.

\subsection{Jam}

Jam is a product made by boiling fruit pulp with sugar and citric acid to a desirable thick consistency. The ideal fruit jam should have a minimum of $45 \%$ pulp, $68 \%$ total soluble solids and $0.5 \%$ acidity. The best-quality jam can be prepared from the varieties which have low fiber content and higher pulp percentage [69]. To prepare aonla jam, first the pulp is extracted from the fruit. This pulp is mixed with the desired quantity of sugar and citric acid, and this mixture is cooked to the desired consistency. The end point is judged by using a refractometer $\left(68^{\circ} \mathrm{Brix}\right)$ or by drop or sheet tests (figure 5). The jam can be prepared with $1 \mathrm{~kg}$ of pulp, $1.25 \mathrm{~kg}$ of sugar and $5 \mathrm{~g}$ of citric acid.

In another method, aonla fruit pulp (50\%) is taken and 67\% sugar is added. Herbs and plants such as 5\% asparagus and 2\% ashwagandha extract will increase its medicinal properties. The mixture is cooked and citric acid is added (acidity 1.2\%). After judging the end point $\left(68^{\circ} \mathrm{Brix}\right)$, it is poured into clean sterilized glass jars; upon the setting of the jam, the lids of the jars are closed, ensuring an air-tight seal ${ }^{1}$.

\subsection{Sauce}

Five kg of sauce containing $50 \%$ aonla pulp and $50 \%$ tomato pulp with $75 \mathrm{~g}$ sugar, $10 \mathrm{~g}$ salt, $60 \mathrm{~g}$ onion, $6 \mathrm{~g}$ garlic, $12 \mathrm{~g}$ ginger, $5 \mathrm{~g}$ red chilies and $12 \mathrm{~g}$ hot spices were prepared. Acetic acid and sodium benzoate as preservatives were added at a concentration of $0.3 \mathrm{~g} \cdot \mathrm{kg}^{-1}$ of product. Finally, the sauce was poured into glass bottles and

\footnotetext{
${ }_{1}$ Value-added products, http://practicalaction.org/practicalanswers/ www.PracticalAction.org, 2007.
} 


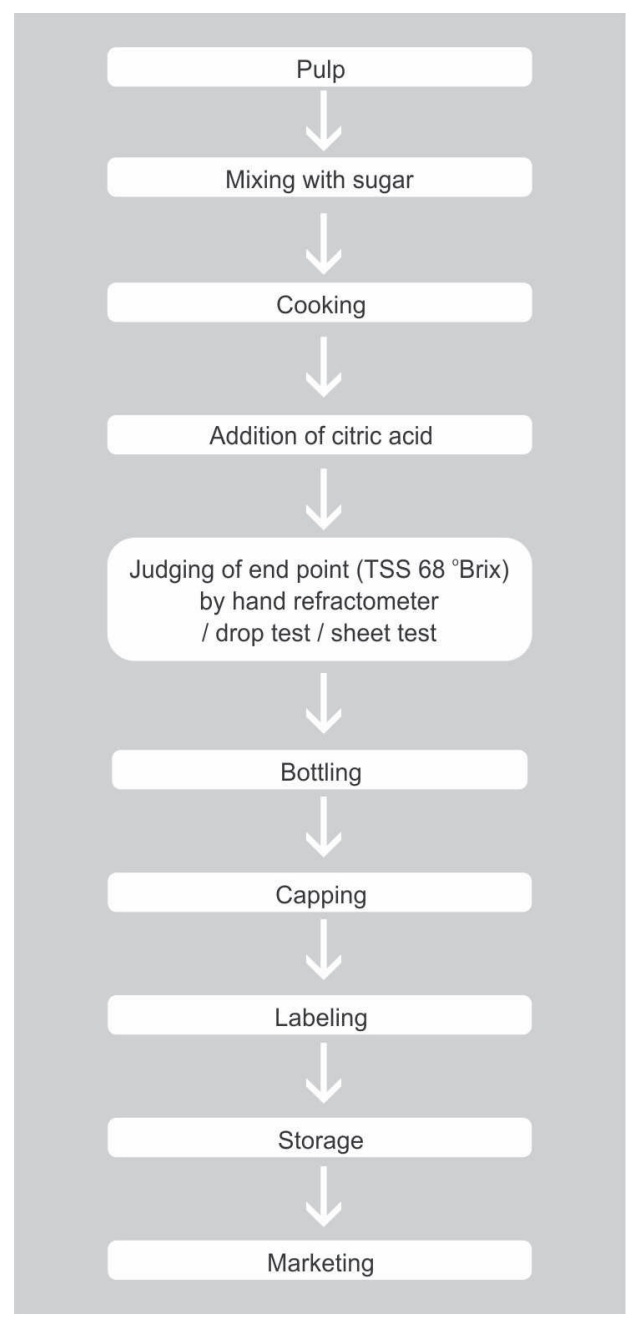

\section{Figure 5.}

Flow sheet for preparation of aonla jam.

crown-corked, followed by processing in boiling water for $30 \mathrm{~min}$ and then air-cooling (figure O). The product was highly acceptable even after a storage period of more than 9 months ${ }^{1}$.

\subsection{Aonla pickle}

Small-sized aonla fruits, which are not suitable for preparation of preserve or other confectionery items, may be utilized for pickle-making [14]. To improve upon the texture of the fruit and also to remove astringency, brining is important in pickling. For

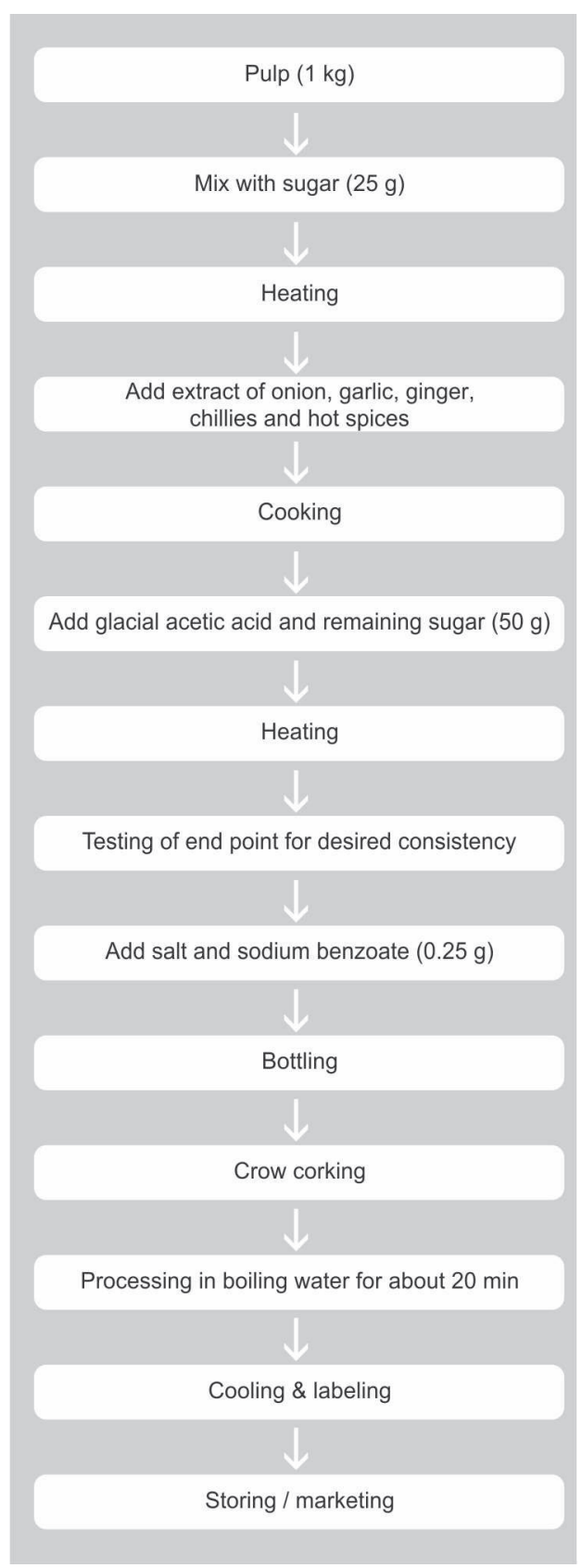

Figure 6.

Flow sheet for preparation of aonla sauce. preparation of aonla pickle, it is necessary to add oils, spices, etc., and to leave it for a few days in the sunshine. After a few days, when the pickle is ready, it has to be stored at room temperature (figure 7 ).

Premi et al. suggested that, for curing aonla fruits, brining a solution containing potassium metabisulfite was more effective 
Table I.

Recipe for Chavanprash.

$$
\begin{gathered}
1.5 \mathrm{~kg} \text { of sugar } \\
1 \mathrm{~kg} \text { of aonla } \\
20 \mathrm{~g} \text { of butter (ghee) }
\end{gathered}
$$

$10 \mathrm{~g}$ of each of the following items:

black pepper, javitri, jayphal, clove, small cardamom, large cardamom, dried ginger, small pipali, caveman, banslochan, ashwagandha, satavari, linseed oil

$5 \mathrm{~g}$ of each of the following items:

bala, jeevanti, pushakarmul, bayaskashta, haritaki, guruchi, nilkamal

$4 \mathrm{~g}$ of dasmul

$1 \mathrm{~g}$ of gabharak bhasm and of muktasukti pishti

\section{Figure 7.}

Flow sheet for preparation of aonla pickle.

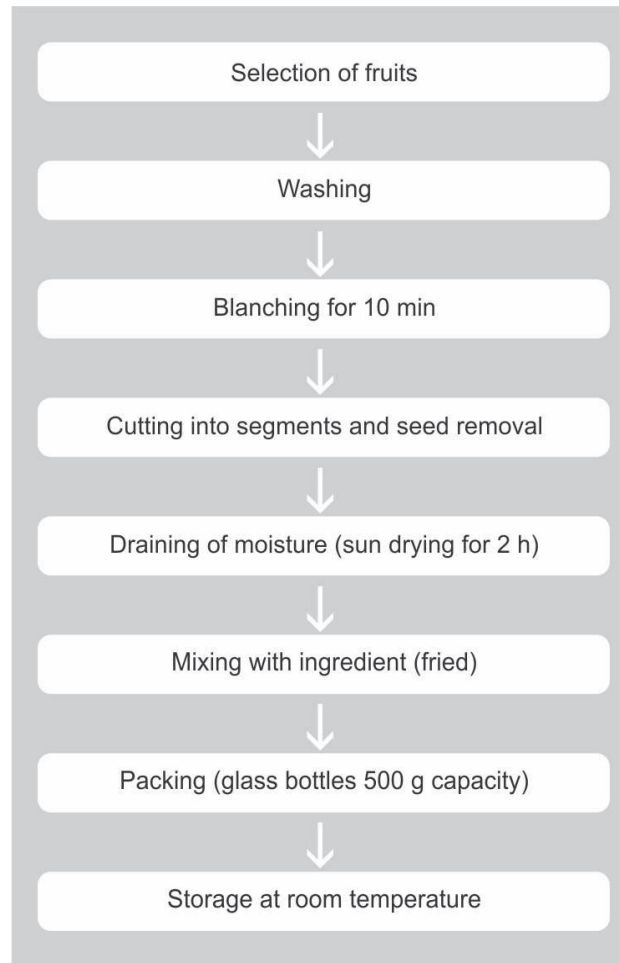

for long-term storage than dry salting or other pretreatments [70]. This resulted in less white specks and better retention of texture and nutrients.

\subsection{Chavanprash}

Chavanprash is a health tonic mentioned in the Indian system of medicine, i.e., Ayurveda. It is prepared by mixing the aonla pulp and sugar while cooking. In this mixture, spices and medicinal plant extracts are added for further cooking (table I). Chavanprash is claimed to be the best immuno-modulator (Rasayana) formulation, specifically recommended for all metabolic diseases, viz., chronic infections, pulmonary tuberculosis, asthma and cough. It is interesting to note that several of its ingredients still are used ethnomedicinally for all aforesaid diseases, thus supporting the properties attributed to it. It has been successfully used as a preventative and curative tonic and is also useful during chronic constipation and urinary infections [71, 72]. It revitalizes the metabolic functions and cures gas, cough and abnormality [71, 73].

\section{Discussion}

Aonla is one of the most highly nutritious and richest sources of vitamin C. So, it is recommended for consumption throughout the year. However, lack of awareness regarding the importance of the fruit, the seasonal nature of its availability, low total area and production, and its short shelf life are some of the reasons why its utilization in a commercial way has not been of great success to date. Processing of the fruits into different value-added products (viz., jam, jelly, candy, dried aonla, chavanprash, sauce, etc.) would go a long way in increasing its popularity and decreasing the postharvest losses.

\section{Conclusions}

Aonla may be an important fruit in the future due to its high medicinal and nutritional value, high productivity per unit area and suitability even in the wastelands. The growing popularity of alternative medicine, health foods and herbal products is enhancing the requirement for aonla fruit. The fruit is rich in vitamin $\mathrm{C}$, protein, fat, crude fiber, starch, sugars and minerals. The fruit is also rich in tannins. It has immense scope for processing and value addition as the fruit is 
not consumed fresh or in the raw state, as it is highly acidic and astringent.

Although aonla cultivation is now wellestablished in India, improvement in technologies with respect to production, protection, postharvest handling and utilization is required for economically sustained growth. The research and development program for aonla is fairly weak in the country. Lack of scientific knowledge regarding aonla restricts its market. In the future, demand for aonla will grow manifold as now its attributes are known to the international community. The main research in the country has mostly been production-oriented. There is a need for improved products through technology intervention.

\section{References}

[1] Jain S.K., Khurdiya D.S., Vitamin C enrichment of fruit juice based ready-to-serve beverages through blending of Indian gooseberry (Emblica officinalis Gaertn.) juice, Plant Foods Hum. Nutr. 59 (2004) 63-66.

[2] Kumar S.P., Sagar V.R., Influence of packaging materials and storage temperature on quality of osmo vac dehydrated aonla segments, J. Food Sci. Technol. 46 (2009) 259-262.

[3] Shankar G., Aonla for daily requirement of vitamin C, Indian Hortic. 13 (1969) 9-15.

[4] Chauhan O.P., Srivastava S., Pandey P., Rao G.K., A study on the development of aonla blended sauce, Bev. Food World 32 (2005) 615-618.

[5] Pokharkar S.M., Development and performance evaluation of aonla shredding machine, Bev. Food World 32 (3) (2005) 52-53.

[6] Nath V., Singh I.S., Kumar S., Evaluation of aonla cultivars for their shelf life at ambient temperature, Narendra Deva J. Agric. Res. 7 (1) (1992) 117-120.

[7] Singh I.S., Pathak R.K., Dwivedi R., Singh H.K., Aonla production and post-harvest technology, N.D. Univ. Agric. Technol. Kumarganj, Tech. Bull., Faizabad, India,1993.
[8] Khopde S.M., Priyadarshani K.I., Mohan H., Gawandi V.B., Satav J.G., Yakshmi J.V., Banavaliker M.M., Biyani M.K., Mittal J.P., Characterizing the antioxidant activity of amla (Phyllanthus emblica) extract, Current Sci. 81 (2) (2001) 185.

[9] Frei B., England L., Ames B., Ascorbate is an outstanding antioxidant in human blood plasma, Proc. Natural Acad. Sci., U.S.A., 86, 1989, pp. 6377-6381.

[10] Ray P.K., Majumdar S.K., Anti microbial activity of some Indian plants, Econ. Bot. 30 (1976) 317-320.

[11] Ghorai K., Sethi V., Varietal suitability of amla (Desi and Banarsi) fruits for storage and preservation, Indian Food Packag. 50 (1) (1996) 11-15.

[12] Kumar S., Nath V., Storage stability of amla fruits: a comparative study of zero-energy cool chamber versus room temperature, $\mathrm{J}$. Food Sci. Technol. 30 (3) (1993) 202-203.

[13] Pathak P.K., Preeti D., Kumar S., Effect of post-harvest treatments on shelf-life of aonla (Emblica officinalis) fruits damaged during harvesting, J. Food Sci. Technol. 46 (2009) 283-285.

[14] Goyal R.K., Patil R.T., Kingsly A.R.P., Himanshu W., Pradeep K., Status of post harvest technology of aonla in India - A review, Am. J. Food Technol. 3 (2008) 13-23.

[15] Singh S., Singh A.K., Joshi H.K., Bagle B.G., Dhandar D.G., Evaluation of packages for transportation and storability of aonla (Emblica officinalis) under semi-arid environment of Western India, J. Food Sci. Technol. 46 (2009) 127-131.

[16] Beinyuy E., Joseph E., A solar tunnel drier for natural convection drying of vegetables and other commodities in Cameroon, Agric. Mech. Asia Afr. Lat. Am. 35 (2004) 31-35.

[17] Akhtar M.S., Ramzan A., Ali A., Ahmad M., Effect of amla fruit (Emblica officinalis Gaertn.) on blood glucose and lipid profile of normal subjects and type 2 diabetic patients, Int. J. Food. Sci. Nutr. (2011).

[18] Nampoothiri S.V., Prathapan A., Cherian O.L., Raghu K.G., Venugopalan V.V., Sundaresan A., In vitro antioxidant and inhibitory potential of Terminalia bellerica and Emblica officinalis fruits against LDL oxidation and key enzymes linked to type 2 diabetes, Food Chem. Toxicol. 49 (1) (2011) 125-131. 
[19] Babu P.S., Mainzen S., Prince P., Antihyperglycaemic and antioxidant effect of hyponidd, an ayurvedic herbomineral formulation in streptozotocin-induced diabetic rats, J. Pharm. Pharmacol. 56 (11) (2004) 1435-1442.

[20] Sabu M.C., Kuttan R., Anti-diabetic activity of medicinal plants and its relationship with their antioxidant property, J. Ethnopharmacol. 81 (2) (2002) 155-160.

[21] Burkill I.H., A dictionary of the economic products of the Malay peninsula, Vol. 1, Min. Agric. Coop., Kuala Lumpur, Malaysia, 1966.

[22] Tripathi K.P., Essentials of medical pharmacology, 5th Ed., Jaypee Brothers Med. Publ. (P) Ltd., New-Delhi, India, 2003, 759 p.

[23] Chadha K.L., Handbook of horticulture, ICAR Publ., New-Delhi, U.K., 2003.

[24] Tripathi S.C., Srivastava M., Ethnomedicinal flora of Euphorbiaceae used in dermatological problems, Indian J. Trad. Knowl. 9 (2) (2010) 318-320.

[25] Mehmood M.H., Siddiqi H.S., Gilani A.H., The antidiarrheal and spasmolytic activities of Phyllanthus emblica are mediated through dual blockade of muscarinic receptors and $\mathrm{Ca}^{2+}$ channels, J. Ethnopharmacol. 133 (2) (2011) 856-865.

[26] Stuart G.A., Chinese materia medica vegetable kingdom, Am. Presbyt. Mission Press, Shanghai, China, 1911, 558 p.

[27] Singh E., Sharma S., Pareek A., Dwivedi J., Yadav S., Sharma S., Phytochemistry, traditional uses and cancer chemopreventive activity of amla (Phyllanthus emblica): The sustainer, J. Appl. Pharm. Sci. 02 (01) (2011) 176-183.

[28] Sancheti G., Jindal A., Goyal R.K., Chemopreventive action of Emblica officinalis on skin carcinogenesis in mice, Asian Pac. J. Cancer Prev. 6 (2005) 197-201.

[29] Phromnoi K., Yodkeeree S., Anuchapreeda S., Limtrakul P., Inhibition of MMP-3 activity and invasion of the MDA-MB-231 human invasive breast carcinoma cell line by bioflavonoids, Acta Pharmacol. Sin. 30 (2009) 1169-1176.

[30] Sun S.Y., Hail N. Jr., Lotan N., Apoptosis as a novel target for cancer chemoprevention, J. Natl. Cancer Inst. 96 (2004) 662-672.

[31] Ghobrial I.M., Witzig T.E., Adjei A.A., Targeting apoptosis pathways in cancer therapy, CA Cancer J. Clin. 55 (2005) 178-194.
[32] Krishnaveni M., Mirunalini S., Amla - The role of ayurvedic therapeutic herb in cancer, Asian J. Pharm. Clin. Res. 4 (3) (2011) 13-17.

[33] Madhuri S., Pandey G., Verma K.S., Antioxidant, immunomodulatory and anticancer activities of Emblica officinalis: an overview, Int. Res. J. Pharm. 2 (8) (2011) 38-42.

[34] Singh I.K., Pathak R.K., Evaluation of aonla (Emblica officinalis Gaertn.) varieties for processing, Acta Hortic. 208 (1987) 173-177.

[35] Mehta S., Evaluation of different cultivars of aonla (Emblica officinalis Garten) for processing, CCS HAU, Thesis, Hisar, India, 1995.

[36] Vimala Y., Rachel K.V., Pramodini Y., Umasankar A., Usage of Indian gooseberry (Emblica officinalis) seeds in health and disease prevention, in: Preedy V.R., Watson R.R., Patel V.B. (Eds.), Nuts and seeds in health and disease prevention, 2011, pp. 663-670.

[37] Tandon D.K., Yadav R.C., Sood S., Kumar S., Dikshit A., Effect of blanching and lye peeling on the quality of aonla candy, Indian Food Packag. 57 (6) (2003) 147-149.

[38] Bhosale V.I., Kute L.S., Kadam S.S., Studies on preparation of ready to serve beverage from aonla: mango juice blend, Beverage Food World 27(2) (2000) 24-27.

[39] Pandey G., Dravyaguna Vijnana (Materia Medica-Vegetable Drugs), Part I, Vol. 2., Krishnadas Acad., Varanasi, India, 2002, $102 \mathrm{p}$.

[40] Kirtikar K.R., Basu B.D., Phylanthus emblica, in: Indian medicinal plants, 2nd ed., Lalit Mohan Basu Publ., Calcutta, India, 1993, $2220 \mathrm{p}$.

[41] Chopra R.N., Chopra I.C., Handa K.L., Kapur L.D., Chopra's indigenous drugs of India, 2nd ed., Dhur U.N. \& sons Pvt. Ltd., Calcutta, India, 1958.

[42] Barthakur N.N., Arnold N.P., Chemical analysis of the emblic (Phyllanthus emblica L.) and its potential as a food source, Sci. Hortic. 47 (1991) 99-105.

[43] Sivakumar V., Sundaram K.S., Effect of different maturity stages on fruit quality traits or physiochemical characters of aonla cv. Na-7, Plant Arch. 10 (2) (2010) 903-905.

[44] Pathak R.K., Om H., Dwivedi R., Collection, maintenance of evaluation of aonla (Emblica officinalis Gaertn.) germplasm, Indian J. Plant Genet. Resour. 2 (1989) 84-86. 
[45] Singh B.P., Pandey G., Sarolia D.K., Pandey M.K., Pathak R.K., Shelf-life evaluation of aonla cultivars, Indian J. Hortic. 62 (2005) 137-140.

[46] Dhumal S.S., Karale A.R., Garande V.K., Patil B.T., Masalkar S.D., Kshirsagar D.B., Shelf life of aonla fruits: Influenced by post harvest treatments and packaging materials, Indian J. Agric. Res. 42 (3) (2008) 189-194.

[47] Singh R., Kumar S., Effect of different storage conditions on the shelf life of aonla (Emblica offiinalis G.) cv. Chakaiya, Haryana J. Hortic. Sci. 26 (1-2) (1997) 12-15.

[48] Singh S., Singh A.K., Joshi H.K., Bagle B.G., Dhandar D.G., Heat unit summation - an index for predicting fruit maturity in aonla (Emblica officinalis Gaertn.) under semi arid tropics of Western India, in: Proc. 8th Indian Agric. Sci. Farmers Congr., B.H.U., Varanasi Bioved Res. Commun. Cent., Allahabad, India, 2005, pp. 123.

[49] Shetty H.A.H., Blue mold of aonla (Phyllanthus emblica L.), Curr. Sci. 28 (1954) 208.

[50] Tripathi V.K., Singh M.B., Singh S., Studies on comparative compositional changes in different preserved products of amla (Emblica officinalis Garten) var. Banarasi, Indian Food Packag. 42 (4) (1988) 60-65.

[51] Nath V., Sharma R.K., Screening of aonla (Emblica officinalis Gaert.) cultivars for processing, Prog. Hortic. 30 (1-2) (1998) 76.

[52] Kalra C.L., The chemistry and technology of aonla (Phyllanthus emblica L.) a resume, Indian Food Packag. 38 (4) (1988) 67.

[53] Jain S.P., Tripathi V.K, Ram H.B., Singh S., Optimum stage of maturity for preservation of amla preserve, Part II, Indian Food Packag. 37 (6) (1983) 85-90.

[54] Tasduq S.A., Mondhe D.M., Gupta D.K., Baleshwar M., Johri R.K., Reversal of fibrogenic events in liver by Emblica officinalis (fruit), an Indian natural drug, Biol. Pharm. Bull. 28 (7) (2005) 1304-1306.

[55] Jayaweera D.M.A., Medicinal plants used in Ceylon, Part 2, Natl. Sci. Counc. Sri Lanka, Colombo, Sri Lanka, 1980.

[56] Khan K.H., Roles of Emblica officinalis in Medicine - A review, Bot. Res. Int. 2 (4) (2009) 218-228.

[57] Doymaz I., Air-drying characteristics of tomatoes, J. Food Eng. 78 (2007) 12911297.
[58] Mudgal V.D., Pande V.K., Thin layer drying kinetics of bittergourd (Momordica charantia L.), J. Food Sci. Technol. 46 (2009) 236-239.

[59] Verma R.C., Gupta A., Effect of pre-treatments on quality of solar-dried amla, J. Food Eng. 65 (2004) 397-402.

[60] Alam M.S., Amarjit S., Sawhney B.K., Response surface optimization of osmotic dehydration process for aonla slices, J. Food Sci. Technol. 47 (1) (2010) 47-54.

[61] Damame S.V., Gaikwad R.S., Patil S.R., Masalkar S.D., Vitamin C content of various aonla products during storage, Orissa $\mathrm{J}$. Hortic. 30 (2002) 19-22.

[62] Sagar V.R., Kumar R., Preparation and storage study of ready-to-eat dehydrated gooseberry (aonla) shred, J. Food Sci. Technol. 43 (2006) 349-352.

[63] Vijayanand P., Kulkarni S.G., Reena P., Aksha M., Ramana K.V.R., Effect of processing on gooseberry fruits and quality changes in dehydrated gooseberry powder during storage, J. Food Sci. Technol. 44 (2007) 591-594.

[64] Tirgar P.R., Jadav P.D., Sheth D.B., Desai T.R., Therapeutic role of anti-oxidant properties of Emblica officinalis (amla) in streptozotocin induced type I diabetic rats, Pharmacologyonline 1 (2010) 728-743.

[65] Ram R.B., Meena M.L., Sonkar P., Lata R., Upadhyay A.K., Standardization and evaluation of blended aonla (Emblica officinalis Gaertn.) and bael (Aegle marmelos Correa) RTS beverages, Plant Arch. 11 (1) (2011) 205-208.

[66] Chandan K., Prashanth S.J., Nataraj S.K., Indudhara S.M., Rokhade A.K., Preparation of dehydrated slices and RTS beverages from aonla (Emblica officinalis Gaertn.) fruits, Int. J. Agric. Sci. 6 (1) (2010) 300-304.

[67] Pathak S., Post-harvest technology of aonla (Emblica officinalis Gaertn.) fruits, N.D. Univ. Agric. Technol., Thesis, Faizabad, India, 1988.

[68] Singh P., Singh J.P., Chopra C.S., Technoeconomic study on processing of aonla products, Beverage Food World 30 (2003) 68-69.

[69] Pareek S., Rathore N.S., Kaushik R.A., Aonla (Emblica oficinalis Gaertn.): Post harvest handling and processing technology, Rajasthan Coll. Agric., Techn. Bull. No. 1, Udaipur, India, 2011, 45 p. 
[70] Premi B.R., Sethi V., Bisaria G., Preparation of instant oilless pickle from aonla (Emblica officinalis Gaertn.), Indian Food Packag. 24 (2002) 72-75.

[71] Anon., Raw materials, in: Shastri B.N. (Ed.), Wealth of India, Vol. III, CSIR, New-Delhi, India, 1952.

[72] Gupta O.P., Srivastava T.N., Gupta S.C., Badola D.P., Ethnobotanical and phytoche- mical screening of high attitude plants of Ladakh, Bull. Medico-Ethno Bot. Res. 2 (1981) 67-88.

[73] Ojha J.K., Bajpai H.S., Sharma P.V., Khanna M.N., Shukla P.K., Sharma T.N., Chavanprash as an anabolic agent - Experimental study (Prelim. work), J. Res. Indian Med. 8 (2) (1973) 11-13.

\section{Embalaje, almacenaje y valor añadido del amalaki, un fruto poco utilizado, en India.}

Resumen - El producto. El amalaki (Emblica officinalis Geartn.), rey de los frutos de las zonas áridas, popularmente conocido bajo el nombre de "grosella de la India", es un frutito subtropical menor, muy cultivado en la India del Norte. La India ocupa la primera posición mundial de superficie y volumen de producción de este fruto. Se le considera como "un fruto curioso para la salud", dadas sus propiedades excepcionales. Usos. El fruto del amalaki se emplea mucho para curar numerosas enfermedades como la diabetes, la tos, el asma, la bronquitis, los dolores de cabeza, la dispepsia, los cólicos, las flatulencias, las enfermedades de la piel, la lepra, ictericia, el escorbuto, la diarrea y el cáncer. Embalaje. Para prolongar la duración de conservación de los frutos, se pueden emplear diferentes materiales de embalaje, tales como mallas de nailon, bolsas de polietileno perforadas, cajas de cartón ondulado ventilado, bolsas de yute, cajas de madera, etc. Almacenaje. El almacenaje refrigerado permite mejorar la duración de conservación de los frutos. Valor añadido. Un gran número de productos, como el zumo exprimido, los bombones, la mermelada, el chutney, etc., está preparado a partir de los frutos del amalaki. La introducción de estos productos en la alimentación contribuye a mejorar el valor nutricional de los almuerzos indios. Discusión. El bajo coste de los productos, así como sus buenas cualidades sensoriales, nutricionales y de duración de vida hacen que los productos transformados a partir de frutos del amalaki sean apropiados para la comercialización. Con el fin de tener un buen ingreso del amalaki, el fruto debe ser comercializado rápidamente en el mercado pero, para obtener beneficios, es necesario disponer de instalaciones de almacenaje adecuadas.

Emblica officinalis / frutas / usos tradicionales / maquinaria de embalaje / almacenamiento / valor añadido 